\title{
A STUDY OF CORRELATION BETWEEN STATURE AND ARM SPAN OF NORTH INDIAN POPULATION
}

\author{
Roberton Gautam, Vasundhara Kulshreshtha, Pradeep Singh, Anshu Gupta \\ Department of Anatomy, S.N. Medical College, Agra, UP, India
}

\begin{abstract}
Introduction: Age, sex and stature are primary characteristics for identification of an individual. Stature has a definite and proportional biological relationship with each and every part of human body i.e. head, neck, trunk and extremities.

Material \& Methods: The present study comprised of 300 medical students belonging to North India of age group between 18 yrs. to 25 yrs. of S.N. Medical College, Agra. The two anthropometric parameters, arm span and stature were used to calculate mean, standard deviation and Pearson's correlation coefficient.

Results: The Pearson's correlation coefficient was found to be 0.9171 and $p$ value was calculated to be $<0.00001$ thus, showing a significant positive correlation between the stature and arm span for the North Indian population.

Conclusion: The correlation between arm span and the stature in adult males and females, was found to be an accurate predictor of stature. Thus it becomes an important anthropologic tool for the scientists in limb reconstruction surgeries. In mass disasters like train accidents, earthquakes, etc. and where the subject is in highly decomposed, fragmentary and mutilated form, it can be helpful in determining the identity of an individual.
\end{abstract}

Keywords: Arm Span, stature, anthropology.

\section{INTRODUCTION}

Measurement of body size such as height and weight are required for assessment of growth and nutritional status of an individual [1]. Stature is an important clinical parameter in risk stratification and to identify an unknown cadaver [1], patients with deformity of limbs or amputation [2] or cadaver where limb is absent or mutated or decomposed or animal attacked or mass disaster [3].

Identification of disproportionate growth abnormalities in individuals, disease like skeletal dysplasia, in medicolegal cases, or spinal deformities caused by accidents, or formed by surgical procedures [4]. Among the assessment of various other anthropometric measures, including knee height, height of spine, face breadth [5], sitting height and demi span, the various studies indicate that arm span has the strongest correlation with standing height $[6,7]$.

Here, we have made an effort to find out correlation between arm span and height in North Indian population. The data and statistics derived from our study can be of importance in various medical fields like forensic, anthropologic studies and archaeologists as well. The aim of the study was to determine the stature from arm span in both the sexes in North Indian population and to find a correlation between stature and arm span and derive a regression equation for stature from arm span.

\section{MATERIALS AND METHODS}

The study comprised of 300 medical students between 18 yrs. to 25 yrs. of age group who were apparently healthy of SN Medical College, Agra. The

\footnotetext{
Address for Correspondence:
}

Dr Roberton Gautam, H. No. 289, Ambedkar Puram, Sector 5, Avas Vikas-3, Panki Road, Kalyanpur, Kanpur- 208017

Mob: 8005183804 Email: roberton.gautam@gmail.com 
lower age limit of $18 \mathrm{yrs}$. was chosen as by this age the skeletal maturity is almost completed. The study excluded subjects having any spinal or bone deformity e.g. scoliosis, kyphosis, arthritis etc. An informed written consent was taken from the subjects prior to the study.

In this study, the body height was measured as the perpendicular distance between the top of the head and the bottom of the feet. It was measured using stadiometer to the nearest 0.1 centimetres in bare feet with the students standing upright against stadiometer. The students had their feet together and moved back until their heels touched the bottom of the stadiometer. Their buttocks and upper part of their back were in contact with the stadiometer, but their head did not touch the stadiometer. The student's head were in horizontal plane. The vertex was the highest point on their head, to lie in the Frankfort plane to align their head properly [8].

As arm span is the anthropometric measurement of the length from the tip of the middle finger of left and right hands when raised parallel to the ground at shoulder height at 180 degrees angle. It was measured using a calibrated steel tape to the nearest 0.1 centimetres in bare feet on a level concrete floor with their upper backs, buttocks and heels against the wall providing support. The student's head were also in the Frankfort plane and the arms outstretched at right angles to the body with palms facing forwards. The measurements were taken from middle fingertip of one side to middle fingertip of other side, with the tape passing in front of clavicles (Fig. 1) [9].

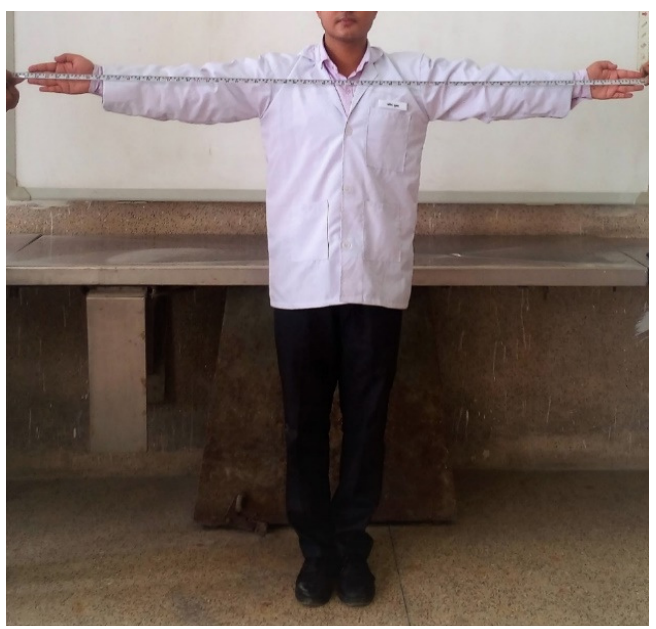

Fig. 1: Photograph showing the method used for measurement of arm span
Body height and arm span of each subject were taken thrice and then their average was calculated. Thereafter, the mean height and mean of arm span was calculated for all the students. The standard deviation and $p$ value were calculated, eventually the regression equation was calculated using SPSS software, version 22.

\section{OBSERVATIONS}

In a sample $(\mathrm{N})$ of 300 students, mean stature was taken as standard to be $164.86 \mathrm{~cm}$, with standard deviation of $8.78 \mathrm{~cm}$, and mean arm span was taken as standard $169.41 \mathrm{~cm}$, with standard deviation of $10.79 \mathrm{~cm}$ (Table 1).

\section{A regression equation is given as: $\mathbf{Y}=\mathbf{b X}+\mathbf{a}$}

The regression formula was calculated using SPSS software version 22 using arm span of the subjects and was given as: $\mathbf{Y}=\mathbf{0 . 7 5 X}+\mathbf{3 7 . 6 3}$

$Y$ is the height of subject that is to be calculated, is the dependent variable. $X$ is the arm span of the subject, an independent variable, values of $b$, the slope and $a$ is intercept in the graph are 0.75 and 37.63 respectively.

Now, by applying regression statistics, in the derived formula above, the stature of subject $(Y)$ was calculated by applying the value of arm span $(X)$ as $169.41 \mathrm{~cm}$ (Table 1).

Height of subject $(Y)=37.63+(0.75 \times 169.41)$ $=164.85 \mathrm{~cm}$, and correlation coefficient $(\mathrm{r})$ between arm span and height is 0.92 (Table 1), while the coefficient of determination $\left(\mathrm{R}^{2}\right)$ is 0.85 using SPSS software, version 22.

Table 1: Relationship of arm span and stature

\begin{tabular}{|l|c|c|}
\hline \multicolumn{1}{|c|}{ Values } & Arm Span & Stature \\
\hline Sample $(\mathrm{N})$ & 300 & 300 \\
\hline Maximum (cm) & 195.00 & 186.80 \\
\hline Minimum (cm) & 142.00 & 142.00 \\
\hline Mean value (cm) & 169.41 & 164.86 \\
\hline Standard deviation & 10.79 & 8.72 \\
\hline Standard error & 0.62 & 0.51 \\
\hline Pearson's correlation coefficient & & 0.92 \\
\hline \multicolumn{2}{|c|}{ p- value } & \multicolumn{2}{|c|}{0.0001 (significant) } \\
\hline
\end{tabular}


The relation between arm span and stature is shown in scattered diagram (Fig. 2), where $x$ axis shows arm span drawn against y axis depicting stature, which shows that the stature and arm span are strongly correlated and they show positive correlation, i.e. in individuals whose arm span are greater, Stature is also found to be large, and viceversa. The $R^{2}=0.850$, which means that $85.0 \%$ of the total variation in arm span was explained by the linear relation with mean stature.

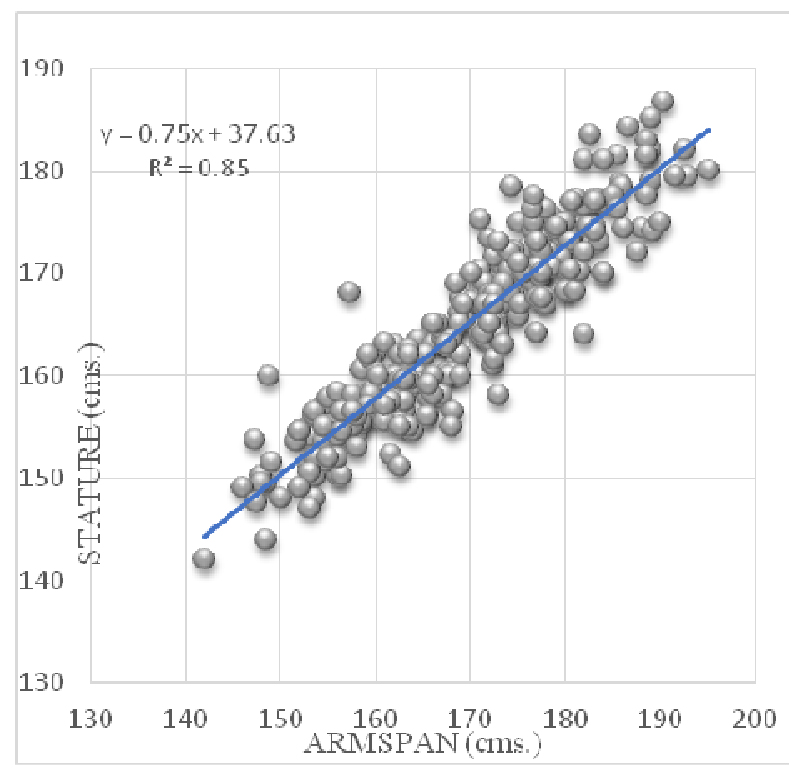

Fig. 2: Graph showing the linear relation between arm span and stature

\section{DISCUSSION}

When the accurate measurement for stature is unobtainable, it is computed using other surrogates [10]. Arm span is the most widely used one. Estimation of stature using various physical measurements has been attempted by many authors. Present study was compared with various previous studies (Table 2). Chumlea et al. (1985) estimated stature from knee height [11.The one variable that proved to be consistently reliable in estimating stature was the arm span. Shah et al. (2013) performed a cross sectional study on 150 MBBS students in one of the medical college of Ahmedabad. Statistical analysis of the data obtained showed strong and significant correlation of 0.9313 between height and arm span [1]. Patel et al. (2012) did work on 273 subjects, showing correlation between stature and five parameters i.e. arm span, hand length, hand breadth, foot length and foot breadth at different degrees, where arm span showed the highest correlation with stature $(r=0.908)$ [12]. Alam et al. (2016) did a study on 124 students in Uttar Pradesh, India. The correlation between stature and arm span was positive and significant $(r=0.798$, $\mathrm{p}<0.05)$ [9]. Body height correlates well with the arm span so it can be used as a reliable marker for stature estimation using regression equation. Nadankutty et al. (2014) did work on 315 subjects of Malaysia and found correlation to be 0.920 between arm span and height, which was strong and positive correlation [2].

Table 2: Comparison of present study with the previous studies done at different parts of Asia

\begin{tabular}{|c|c|c|c|c|}
\hline Authors & $\begin{array}{l}\text { Mean } \\
\text { height } \\
(\mathrm{cm})\end{array}$ & $\begin{array}{l}\text { Mean arm } \\
\text { span } \\
\text { (cm) }\end{array}$ & $\begin{array}{l}\text { Pearson } \\
\text { correlation } \\
\text { coefficient } \\
\text { (r) }\end{array}$ & $p$ value \\
\hline $\begin{array}{l}\text { Shah et al. in } \\
\text { Gujarat (2013) } \\
\text { [1] }\end{array}$ & $\begin{array}{c}168.23 \\
\pm \\
9.38\end{array}$ & $\begin{array}{c}169.92 \\
\pm \\
10.46\end{array}$ & 0.9313 & $<0.0001$ \\
\hline $\begin{array}{l}\text { Patel et al. in } \\
\text { Bhavnagar } \\
\text { (2012) [12] }\end{array}$ & $\begin{array}{c}164.59 \\
\pm \\
9.19\end{array}$ & $\begin{array}{c}167.28 \\
\pm \\
10.73\end{array}$ & 0.9080 & $<0.0001$ \\
\hline $\begin{array}{l}\text { Alam et al. in } \\
\text { east UP } \\
\text { (2016) [9] }\end{array}$ & $\begin{array}{c}167.59 \\
\pm \\
10.38\end{array}$ & $\begin{array}{c}168.67 \\
\pm \\
11.78\end{array}$ & 0.7980 & $<0.0001$ \\
\hline $\begin{array}{l}\text { Nadankutty et } \\
\text { al. in Malaysia } \\
\text { (2014) [2] }\end{array}$ & $\begin{array}{c}163.25 \\
\pm \\
8.68\end{array}$ & $\begin{array}{c}165.87 \\
\pm \\
10.91\end{array}$ & 0.9200 & $<0.0001$ \\
\hline $\begin{array}{l}\text { Present study } \\
\text { in North India } \\
\text { (2018) }\end{array}$ & $\begin{array}{c}164.86 \\
\pm \\
8.78\end{array}$ & $\begin{array}{c}169.41 \\
\pm \\
10.79\end{array}$ & 0.9222 & $<0.0001$ \\
\hline
\end{tabular}

\section{CONCLUSION}

In the present study, a significant positive correlation was observed between arm span and stature in 300 North Indian students of age group between 18-25 yrs. and the estimated stature from arm span was almost equal to their measured mean stature i.e. $164.8560 \mathrm{~cm}$ using the derived regression equation which is $Y=0.75 X+37.63$.

The height was strongly correlated with arm span as $p$ value is $<0.0001$. The finding of the present study indicate that the arm span can be used to accurately predict stature of an individual of North Indians.

\section{REFERENCES}

1. Shah RK, Nirvana AB, Patel JP, Patel B, Kanani S. Estimating stature from arm span measurement in Gujarat region. GCSMC J Med Sci. 2013; 2: 30-32. 
2. Nadankutty J, Lu L A, Liang TY, Stephen JA, Anuar MAR bt K, Yusuf YA. Correlative study of wingspan (armspan) length and body length in students of SEGi University, Malaysia. Open Science Repository Anthropology, Online (open-access), e45011801. 2014; doi:10.7392/openaccess.45011801.

3. Singh A, Kumar A, Chavali KH, Harish D. Use of arm-span and foot length for estimation of height of the person. J Punjab Acad Forensic Med Toxicol. 2012; 12(2):87-91.

4. Hepper NGG, Black LF, Fowler WS. Relationships of lung volume to height and arm-span in normal subjects and in patients with spinal deformity. Am Rev Resp Dis.1965; 91:356.

5. Chawla M, Rajkumar, Tomar S, Ashoka R. Relationship between arm span and height in adult males of North Indian Punjabi population. Journal of Evolution of Medical and Dental Sciences.2013; 2(4):332-339.

6. Jalzem PF, Gledhill RB. Predicting height from arm measurements. J Pediatr Orthop.1993; 13(6):761-5.
7. Mohanty SP, Babu SS, Nair NS. The use of arm span as a predictor of height a study of South Indian women. Journal of Orthopaedic Surgery.2001; 9(1):19-23.

8. Kithmini Kasunka LG, Raj JO, Watson Singh A. Correlation between standing height and arm span in young adults $A$ cross sectional study. Applied Research Journal.2015; 1(4):242-246.

9. Alam T, Singh $S$, Rai R, Shaheen $S$. Correlation between stature and arm Span: A Prospective. Annals of International Medical and Dental Research.2016; 2(3):56.

10. Steele MF, Chenier TC. Arm-span, height, and age in black and white women. Ann Hum Biol. 1990; 17(6):533-41.

11. Chumlea WC, Roche AE, Steinbearagh ML. Estimating stature from knee height for persons 60 to 90 years of age. J Amer Geri Soc. 1985; 33:116-20.

12. Patel PN, Tanna JA, Kalele SD. Correlation between hand length and various anthropologic parameters. International Journal of Medical Toxicology and Forensic Medicine. 2012; 2(2):61-63. 